\title{
Effects of winter Tyre type on roughness and polishing of road surfaces covered with ice and compact snow
}

\author{
Mikko Malmivuo ${ }^{1} \cdot J_{\text {Juha }}$ Luoma $^{2}$ (D) \\ Received: 24 October 2016 / Accepted: 19 December 2016 / Published online: 28 December 2016 \\ (C) The Author(s) 2016. This article is published with open access at SpringerLink.com
}

\begin{abstract}
Purpose This field study was designed to compare to what degree various proportions of studded and unstudded winter tyres affect the roughness and polishing of road surfaces covered with ice and compact snow.

Methods Test cars equipped with studded and unstudded winter tyres drove around a test track according to the designed procedure. The main straight section of the track had five lanes, each with a different proportion of cars with studded tyres: $100 \%, 75 \%, 50 \%, 25 \%$ and $0 \%$ of the respective lane traffic. The remainder were cars with unstudded winter tyres. Each lane included sections of ice and compact snow with subsections for constant speed, braking and acceleration. The lanes were driven 642 times. The ambient temperature was approximately $0{ }^{\circ} \mathrm{C}$ during the test.

Results The overall results showed that there was no substantial difference in friction of the road surface between lanes having $100 \%, 75 \%$ or $50 \%$ of cars with studded tyres. However, the friction was much poorer in lanes having fewer cars with studded tyres.

Conclusions These results suggest that traffic with $50 \%$ of cars having studded tyres results in adequate friction of icy road surfaces in the test conditions.
\end{abstract}

Keywords Snow tyres · Wintertyres · Studded tyres · Icy road surfaces $\cdot$ Road safety

Juha Luoma

juha.luoma@vtt.fi

Innomikko Consulting Ltd, Mäntytie 4, 02270 Espoo, Finland

2 VTT Technical Research Centre of Finland Ltd, TK4, P.O. Box 1000, 02044 VTT Espoo, Finland

\section{Introduction}

Nordic winter tyres designed for snowy and icy driving conditions are widely used in many countries with wintry road conditions involving icy and snowy road surfaces (e.g. Finland, Canada, Norway, Russia and Sweden). Those tyres are either studded or unstudded. Unstudded Nordic winter tyres are allowed in many other countries as well, but total bans on studded tyres have been imposed in e.g. Germany, Japan and many states in the U.S. because of their negative environmental effects. There are also unstudded winter tyres designed specifically for central Europe; however, they are intended primarily for high speed and wet surfaces and not for icy and snowy road surfaces, and are therefore outside the scope of this study.

The main benefit of studded tyres over unstudded ones is their stronger ice grip at temperatures close to $0{ }^{\circ} \mathrm{C}$ [13], which helps drivers control their vehicles on slippery road surfaces. Most researchers appear to agree that studded tyres provide some safety benefit, although the size of this effect is frequently assessed as limited [4, 6-8, 10-12]. Recent studies have also examined whether increased use of electronic stability control can replace studded tyres [5, 12]. Elvik [5] concluded that when full penetration of electronic stability has been achieved in major cities in Norway, the number of accidents will not increase if the use of studded tyres stays at around $15 \%$.

Aside from the overall safety effects of these tyre types, a more specific and long discussed issue has been whether studded tyres prevent wintry roads from becoming overpolished, and whether a certain proportion of them would be needed for the sake of safety. This cannot of course be answered with a single figure, since the degree of slipperiness varies with the weather conditions and is mitigated by several approaches with concurrent effects, such as winter maintenance and tyre properties. Nevertheless, the question is currently relevant, as 
the use of studded tyres is discouraged by many cities in the Nordic countries due to their adverse health effects [9].

The question of roughness and polishing of wintry road surfaces has been addressed in numerous studies. Some of the earlier ones are no longer relevant due to recent developments in the tyre field [e.g. 1, 2], but two relatively recent studies are worth discussing.

Vaa and Giaever [15] compared various proportions of studded and unstudded tyres on icy road surfaces while the ambient temperature varied from $-2{ }^{\circ} \mathrm{C}$ to $-10{ }^{\circ} \mathrm{C}$. After 1000 runs per lane clear differences emerged, and after 1500 runs the friction in the lane involving $80 \%$ of vehicles with studded tyres was $13 \%$ lower compared to the lane with $100 \%$ of vehicles with studded tyres. The corresponding reduction for other lanes were as follows (proportions of vehicles with studded tyres in parentheses): $33 \%$ (60\%), $41 \%(40 \%)$ and $43 \%$ (20\%). In addition, it seems that the effects of studded tyres were rather limited at low temperatures $\left(-5{ }^{\circ} \mathrm{C}\right.$ or colder), whereas when the temperature was higher (from $-2{ }^{\circ} \mathrm{C}$ to $-3{ }^{\circ} \mathrm{C}$ ) the grip was much better for the proportion of $80-100 \%$ vehicles with studded tyres compared to lower proportions. However, Tuononen and Sainio [14] argued that the main results of Vaa and Giaever are not plausible, as the results by ambient temperature were inconsistent.

Tuononen and Sainio [14] themselves examined the effects of the proportion of studded tyres on the friction of an icy test track. Each lane was driven 144 times by the test vehicles. Based on their results, Tuononen and Sainio suggest that the proportion of vehicles with studded tyres can be as low as 25 $50 \%$ with no risk of substantial polishing of the icy road surface. The study has several points to its credit, but it could be asked whether the lanes were used sufficiently compared to the traffic flows on many urban streets or rural roads. Also, the results show that on the acceleration section the friction dropped dramatically if the proportion of vehicles with studded tyres was $0-80 \%$. Tuononen and Sainio argued that acceleration areas are not as critical for safety as braking sections. However, no particular road section can be assessed as unimportant in terms of road safety, because by contrast with a test track, drivers in real traffic may need to apply emergency braking on any section of road.

This field study was designed to compare to what degree various proportions of studded and unstudded winter tyres affect the roughness and polishing of road surfaces covered with ice and compact snow under controlled conditions. More specifically, we aimed to replicate the main features of the test conducted by Tuononen and Sainio [14] with two major exceptions: (1) two types of typical wintry surfaces were included, i.e. surfaces covered with ice and compact snow, whereas Tuononen and Sainio focused on icy surfaces only, and (2) the use of test lanes was far more substantial than in the test of Tuononen and Sainio, i.e. we aimed to get closer to the wear of lanes in road traffic and thereby achieve more valid results.

\section{Method}

\subsection{Design}

The test was conducted on an oval track $1.8 \mathrm{~km}$ in length including two straight sections. The main straight section (A) of the track had five test lanes, each with a different proportion of cars with studded tyres: $100 \%, 75 \%, 50 \%, 25 \%$ and $0 \%$ of the respective lane traffic. The remainder were cars with unstudded winter tyres. Each test lane included sections of ice and compact snow with subsections for constant speed, braking and acceleration.

Another straight section (B) had two lanes for driving at constant speed, one for cars with studded tyres and one for cars with unstudded tyres. The lane surfaces in this section were covered with compact snow. The main purpose of including this section in the test was to ensure interpretable results if the more complex design of section A were to fail. Both sections A and B included an additional reference lane with no test (surface-wearing) vehicles.

\subsection{Equipment}

There were 10 vehicles with studded tyres and 10 vehicles with unstudded tyres for wearing of the road surfaces. All tyres were made by Nokian Tyres and designed for Nordic winter conditions (Hakkapeliitta 8 and R2). The tyres were less than one year old and driven 10,000-20,000 km, but each tyre was in good condition.

The characteristics (e.g. weight, track, tyre condition) of two vehicle groups were matched, although both groups included several makes and models (Table 1). All cars were equipped with a traction control system (ASR) and an antilock braking system (ABS).

Table 1 Make and model of test vehicles and mean stud protrusion in the middle of the test

\begin{tabular}{llll}
\hline \multirow{2}{*}{$\begin{array}{l}\text { Vehicles with } \\
\text { unstudded tyres }\end{array}$} & \multicolumn{2}{l}{ Vehicles with studded tyres } \\
\cline { 2 - 4 } & & \multicolumn{2}{l}{ Mean stud protrusion, mm } \\
\cline { 2 - 4 } & & Front & Rear \\
\hline Toyota Prius & Skoda Superb & 1.5 & 1.1 \\
Ford Mondeo & Seat Altea & 1.1 & 1.2 \\
Skoda Octavia & Mercedes Benz C & 1.1 & 1.7 \\
Ford Mondeo & Volvo V60 & 1.5 & 0.9 \\
Skoda Superb & Mercedes Benz E & 1.3 & 1.6 \\
Audi RS5 & Audi RS5 & 1.3 & 1.3 \\
Audi RS5 & Audi Q5 & 1.5 & 1.4 \\
Audi SQ5 & VW Tiguan & 1.7 & 1.6 \\
Mercedes Benz C & Mercedes Benz C & 1.4 & 1.4 \\
Toyota Land Cruiser & Toyota Hilux & 0.5 & 0.6 \\
\hline
\end{tabular}




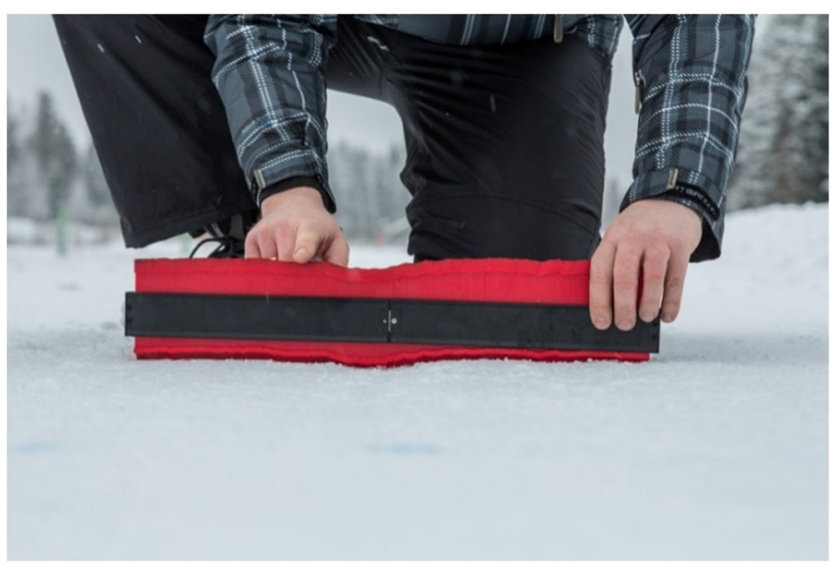

Fig. 1 Measurement of rut depth with a profile gauge

In addition, two similar passenger cars (Volkswagen Golf) were used for friction measurements, one with studded tyres and another with (Nordic) unstudded tyres. Two cars equipped with a different tyre type were selected instead of one for three reasons: (1) to ensure improved reliability of results, (2) the friction with unstudded tyres was of primary interest but the national requirements are based on measurements carried out with studded tyres, and (3) to get more balanced wear of the road surfaces by tyre type.

The mean stud protrusion of tyres on the measurement vehicles before the test was $1.1 \mathrm{~mm}$ for the front tyres and $1.1 \mathrm{~mm}$ for the rear tyres and after the test $1.5 \mathrm{~mm}$ and $1.4 \mathrm{~mm}$, respectively. The vehicles were equipped with Vbox instruments for measuring acceleration, speed and distance using GPS technology.

The depth of ruts on the ice- and snow-covered surfaces was measured with a profile gauge $500 \mathrm{~mm}$ in length (Fig. 1).

The compaction of road surfaces was measured by CTI penetrometer throughout the test [3]. The scale of the CTI penetrometer is $50-100$ and snow test conditions of 70-80 are recommended for tyre comparisons. The compaction ranged from 86 to 94 for icy surfaces and $80-88$ for snowy surfaces.

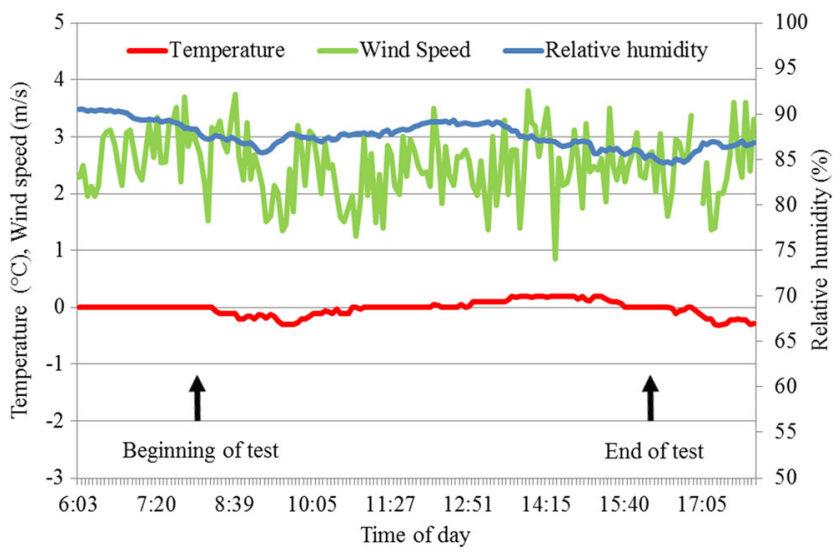

Fig. 2 Weather parameters during the test

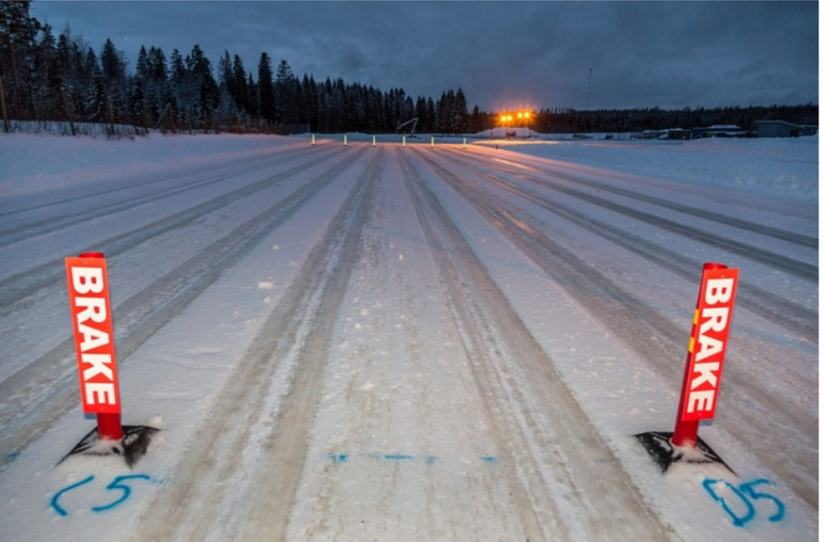

Fig. 3 Icy section for constant speed at the end of the test, $50 \%$ of vehicles with studded tyres

\subsection{Procedure and data analyses}

The icy surface of section A was created by spraying water and allowing it to freeze before the test day. The hard snow surface was prepared by compaction with a roller towed by a lorry, followed by levelling with a steel-mesh drag mat. The slipperiness of section B covered with hard snow was increased by a lorry performing hard braking manoeuvres.

The test vehicles drove around the test track including sections A and B. The use of each lane in section A was balanced among the test vehicles with studded or unstudded tyres, i.e. each vehicle used the lanes as much as the others in the same tyre group. After every 10 runs the proportional use of lanes was as designed. For example, after 10 runs the vehicles with studded tyres had used the test lanes 4, 3, 2, 1 and 0 times and the vehicles with unstudded tyres had used the respective lanes $0,1,2,3$ and 4 times. In section B, there was only one lane for vehicles with studded tyres and one for vehicles with unstudded tyres.

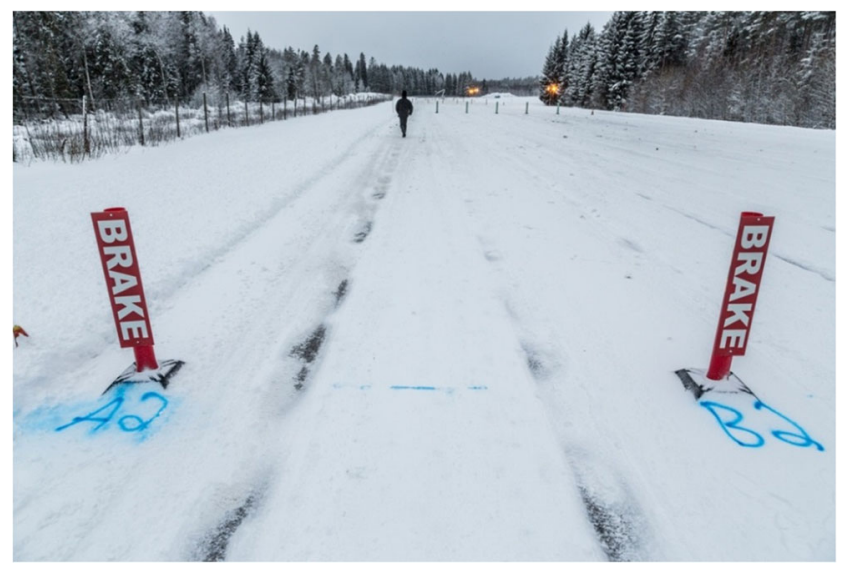

Fig. 4 Compact snow section for braking midway through the test, 100\% of vehicles with studded tyres 


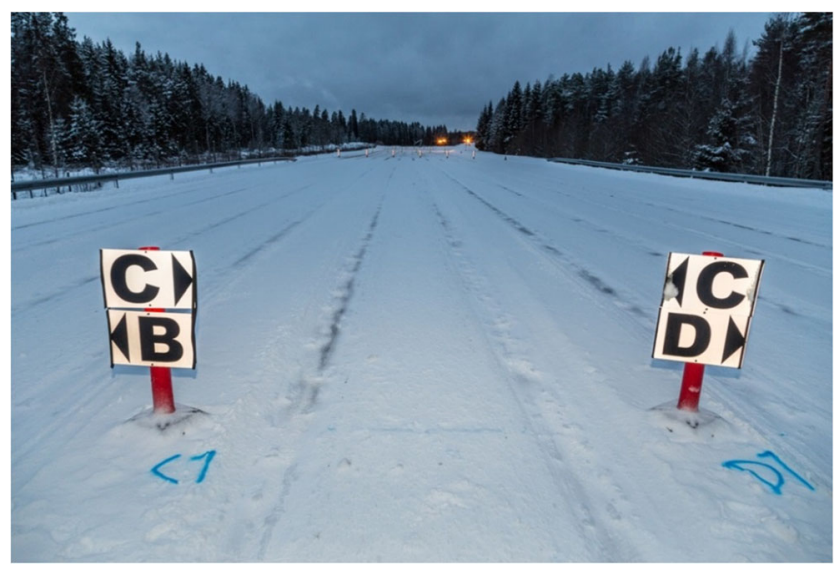

Fig. 5 Compact snow section for constant speed at the end of the test, $50 \%$ of vehicles with studded tyres

The drivers were instructed to drive at $60 \mathrm{~km} / \mathrm{h}$ except in the sections intended for full braking or full acceleration. The measurement of friction was balanced by lane and subsection.

In total, each test vehicle drove 150 runs on the track, resulting in 600 runs per test lane in section $A$ and 1500 runs per test lane in section $B$. The vehicles for friction measurements produced an additional 42 and 105 runs, respectively. Consequently, the total number of runs per test lane was 642

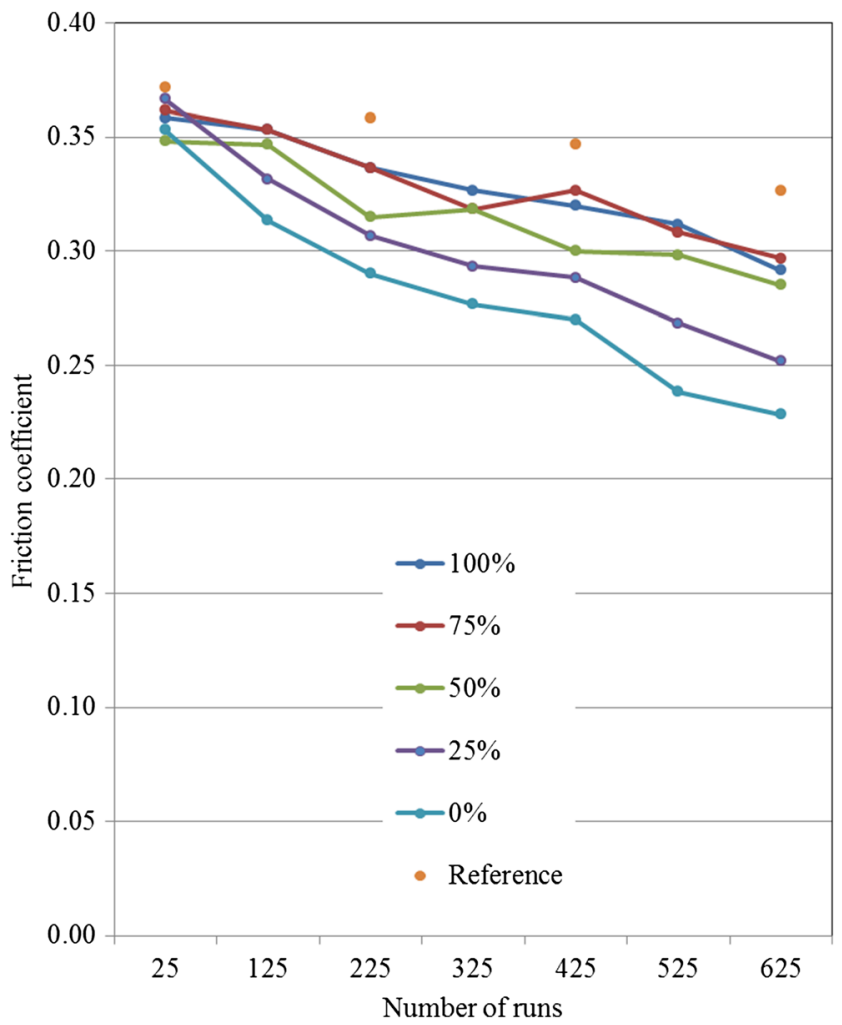

Fig. 6 Mean friction coefficient in section A measured by the vehicle with studded tyres, by proportion of vehicles with studded tyres and number of runs. The mean is calculated for the sections covered with ice and compact snow, including subsections for constant speed, braking and acceleration and 1605 , respectively. The measurement of friction inevitably caused additional braking in each section. However, the proportion of these runs was only $7 \%$ in section A and 3\% in section B.

Vbox provides braking distance and time based on the entered initial and closing speed. In the present study we used $25 \mathrm{~km} / \mathrm{h}$ for the initial speed and $5 \mathrm{~km} / \mathrm{h}$ for the closing speed. A relatively low initial speed was chosen because of the three brakings in each section. Based on the braking distances, the friction coefficient was calculated using formula 1 :

$\mu=\left(\mathrm{v}_{0}^{2}-\mathrm{v}^{2}\right) /(2 \times \mathrm{g} \times \mathrm{L})$

where $\mu=$ friction coefficient; $\mathrm{v}_{0}=$ initial speed $(\mathrm{m} / \mathrm{s}) ; \mathrm{v}_{\mathrm{i}}=$ closing speed $(\mathrm{m} / \mathrm{s}) ; \mathrm{g}=9.81\left(\mathrm{~m} / \mathrm{s}_{2}\right) ; \mathrm{L}=$ braking distance $(\mathrm{m})$.

The depth of the left and right rut of each lane and subsection was measured three times: at the beginning, midway through, and at the end of the test. The measured shape of the rut was copied for calculating its cross-sectional surface with a drawing program. Finally, the mean depth of the rut was determined. However, the range of the profile gauge was not always sufficient, and the gauge's accuracy $( \pm 5 \mathrm{~mm})$ was not good enough to produce results with the desired reliability.

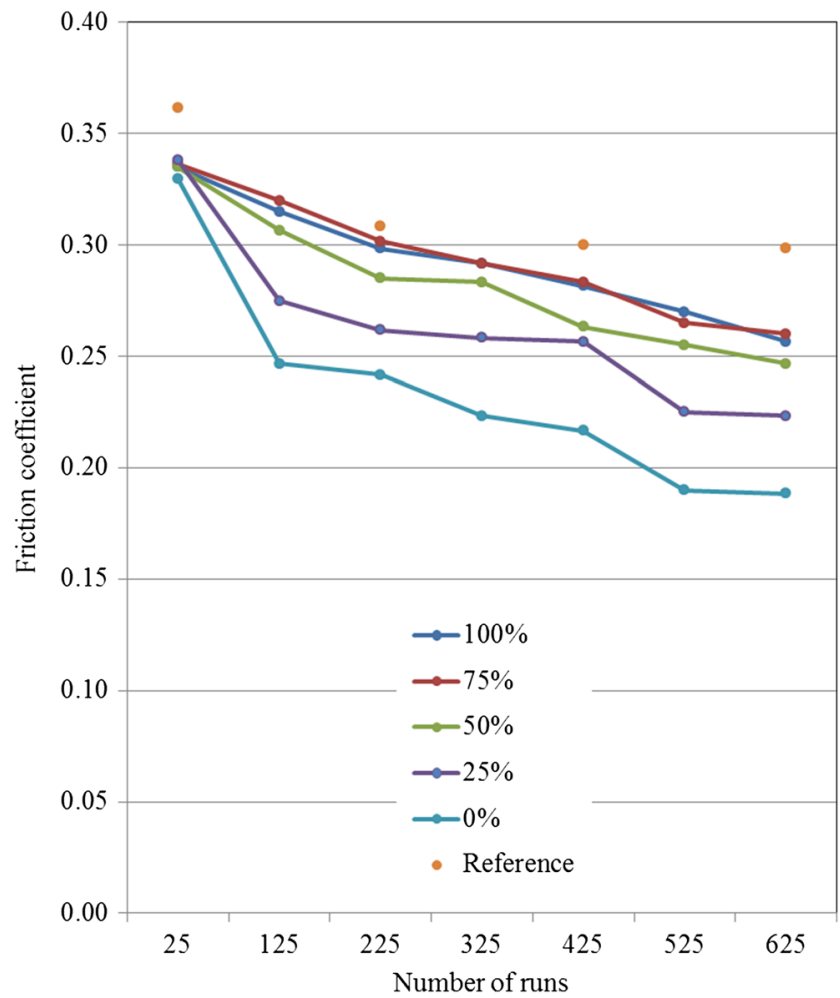

Fig. 7 Mean friction coefficient in section A measured by the vehicle with unstudded tyres, by proportion of vehicles with unstudded tyres and number of runs. The mean is calculated for the sections covered with ice and compact snow, including subsections for constant speed, braking and acceleration 
Table 2 Friction coefficient in section A by type of measurement vehicle, proportion of vehicles with unstudded tyres, road surface and subsection. The cells highlighted in red and orange show friction reductions of more than $20 \%$ and $10 \%$ compared to the lane with $100 \%$ of vehicles with studded tyres, respectively

\begin{tabular}{|c|c|c|c|c|c|c|c|c|c|c|c|c|}
\hline \multirow{3}{*}{$\begin{array}{l}\text { Type of } \\
\text { road } \\
\text { surface }\end{array}$} & \multirow{3}{*}{ Subsection } & \multirow{3}{*}{$\begin{array}{l}\text { Number } \\
\text { of runs }\end{array}$} & \multicolumn{5}{|c|}{$\begin{array}{l}\text { Measured by vehicle } \\
\text { with studded tyres }\end{array}$} & \multicolumn{5}{|c|}{$\begin{array}{l}\text { Measured by vehicle } \\
\text { with unstudded tyres }\end{array}$} \\
\hline & & & \multicolumn{10}{|c|}{ Proportion of studded tyres } \\
\hline & & & $100 \%$ & $75 \%$ & $50 \%$ & $25 \%$ & $0 \%$ & $100 \%$ & $75 \%$ & $50 \%$ & $25 \%$ & $0 \%$ \\
\hline \multirow{21}{*}{$\begin{array}{l}\text { Icy } \\
\text { surface }\end{array}$} & \multirow{7}{*}{$\begin{array}{l}\text { Constant } \\
\text { speed }\end{array}$} & 25 & 0.32 & 0.38 & 0.32 & 0.36 & 0.33 & 0.30 & 0.36 & 0.30 & 0.33 & 0.29 \\
\hline & & 125 & 0.35 & 0.39 & 0.36 & 0.32 & 0.31 & 0.28 & 0.29 & 0.30 & 0.26 & 0.23 \\
\hline & & 225 & 0.36 & 0.38 & 0.35 & 0.28 & 0.29 & 0.29 & 0.31 & 0.29 & 0.24 & 0.24 \\
\hline & & 325 & 0.36 & 0.35 & 0.35 & 0.29 & 0.27 & 0.28 & 0.31 & 0.30 & 0.27 & 0.23 \\
\hline & & 425 & 0.38 & 0.37 & 0.33 & 0.31 & 0.30 & 0.29 & 0.30 & 0.26 & 0.28 & 0.22 \\
\hline & & 525 & 0.36 & 0.35 & 0.38 & 0.30 & 0.29 & 0.30 & 0.28 & 0.32 & 0.25 & 0.23 \\
\hline & & 625 & 0.33 & 0.34 & 0.33 & 0.28 & 0.26 & 0.30 & 0.30 & 0.31 & 0.24 & 0.21 \\
\hline & \multirow{7}{*}{ Braking } & 25 & 0.32 & 0.28 & 0.31 & 0.31 & 0.30 & 0.27 & 0.26 & 0.30 & 0.25 & 0.26 \\
\hline & & 125 & 0.26 & 0.26 & 0.26 & 0.24 & 0.29 & 0.20 & 0.22 & 0.20 & 0.17 & 0.17 \\
\hline & & 225 & 0.26 & 0.26 & 0.25 & 0.24 & 0.24 & 0.21 & 0.19 & 0.19 & 0.17 & 0.15 \\
\hline & & 325 & 0.28 & 0.25 & 0.25 & 0.24 & 0.23 & 0.22 & 0.20 & 0.20 & 0.17 & 0.15 \\
\hline & & 425 & 0.28 & 0.27 & 0.25 & 0.25 & 0.23 & 0.23 & 0.21 & 0.20 & 0.18 & 0.17 \\
\hline & & 525 & 0.28 & 0.26 & 0.26 & 0.25 & 0.21 & 0.22 & 0.20 & 0.21 & 0.18 & 0.16 \\
\hline & & 625 & 0.26 & 0.25 & 0.25 & 0.25 & 0.21 & 0.21 & 0.20 & 0.20 & 0.19 & 0.15 \\
\hline & \multirow{7}{*}{ Acceleration } & 25 & 0.32 & 0.34 & 0.30 & 0.32 & 0.31 & 0.27 & 0.32 & 0.29 & 0.27 & 0.29 \\
\hline & & 125 & 0.30 & 0.27 & 0.29 & 0.30 & 0.28 & 0.26 & 0.25 & 0.23 & 0.23 & 0.22 \\
\hline & & 225 & 0.30 & 0.27 & 0.27 & 0.26 & 0.26 & 0.24 & 0.21 & 0.21 & 0.22 & 0.19 \\
\hline & & 325 & 0.30 & 0.28 & 0.27 & 0.26 & 0.24 & 0.25 & 0.24 & 0.22 & 0.21 & 0.17 \\
\hline & & 425 & 0.30 & 0.29 & 0.27 & 0.26 & 0.24 & 0.25 & 0.22 & 0.23 & 0.21 & 0.18 \\
\hline & & 525 & 0.29 & 0.3 & 0.27 & 0.25 & 0.21 & 0.24 & 0.23 & 0.22 & 0.19 & 0.16 \\
\hline & & 625 & 0.27 & 0.29 & 0.27 & 0.24 & 0.22 & 0.24 & 0.23 & 0.22 & 0.20 & 0.16 \\
\hline \multirow{21}{*}{$\begin{array}{l}\text { Snowy } \\
\text { surface }\end{array}$} & \multirow{7}{*}{$\begin{array}{l}\text { Constant } \\
\text { speed }\end{array}$} & 25 & 0.39 & 0.41 & 0.42 & 0.42 & 0.42 & 0.38 & 0.36 & 0.38 & 0.43 & 0.37 \\
\hline & & 125 & 0.45 & 0.44 & 0.47 & 0.40 & 0.38 & 0.46 & 0.41 & 0.44 & 0.38 & 0.30 \\
\hline & & 225 & 0.45 & 0.45 & 0.41 & 0.39 & 0.38 & 0.44 & 0.46 & 0.40 & 0.38 & 0.35 \\
\hline & & 325 & 0.43 & 0.43 & 0.45 & 0.40 & 0.38 & 0.45 & 0.45 & 0.43 & 0.38 & 0.33 \\
\hline & & 425 & 0.41 & 0.45 & 0.43 & 0.38 & 0.35 & 0.39 & 0.45 & 0.42 & 0.37 & 0.31 \\
\hline & & 525 & 0.37 & 0.41 & 0.38 & 0.32 & 0.27 & 0.36 & 0.39 & 0.35 & 0.29 & 0.23 \\
\hline & & 625 & 0.35 & 0.39 & 0.36 & 0.28 & 0.24 & 0.31 & 0.35 & 0.33 & 0.29 & 0.22 \\
\hline & \multirow{7}{*}{ Braking } & 25 & 0.40 & 0.37 & 0.37 & 0.40 & 0.37 & 0.38 & 0.37 & 0.39 & 0.37 & 0.36 \\
\hline & & 125 & 0.36 & 0.39 & 0.36 & 0.36 & 0.32 & 0.31 & 0.37 & 0.33 & 0.31 & 0.27 \\
\hline & & 225 & 0.31 & 0.34 & 0.32 & 0.33 & 0.27 & 0.29 & 0.32 & 0.34 & 0.27 & 0.28 \\
\hline & & 325 & 0.28 & 0.29 & 0.29 & 0.27 & 0.25 & 0.26 & 0.27 & 0.27 & 0.25 & 0.22 \\
\hline & & 425 & 0.27 & 0.28 & 0.25 & 0.24 & 0.24 & 0.24 & 0.25 & 0.22 & 0.21 & 0.21 \\
\hline & & 525 & 0.29 & 0.26 & 0.23 & 0.22 & 0.22 & 0.25 & 0.24 & 0.20 & 0.20 & 0.17 \\
\hline & & 625 & 0.28 & 0.25 & 0.24 & 0.21 & 0.20 & 0.24 & 0.22 & 0.20 & 0.19 & 0.16 \\
\hline & \multirow{7}{*}{ Acceleration } & 25 & 0.40 & 0.39 & 0.37 & 0.39 & 0.39 & 0.41 & 0.35 & 0.35 & 0.38 & 0.41 \\
\hline & & 125 & 0.40 & 0.37 & 0.34 & 0.37 & 0.30 & 0.38 & 0.38 & 0.34 & 0.30 & 0.29 \\
\hline & & 225 & 0.34 & 0.32 & 0.29 & 0.34 & 0.30 & 0.32 & 0.32 & 0.28 & 0.29 & 0.24 \\
\hline & & 325 & 0.31 & 0.31 & 0.30 & 0.30 & 0.29 & 0.29 & 0.28 & 0.28 & 0.27 & 0.24 \\
\hline & & 425 & 0.28 & 0.3 & 0.27 & 0.29 & 0.26 & 0.29 & 0.27 & 0.25 & 0.29 & 0.21 \\
\hline & & 525 & 0.28 & 0.27 & 0.27 & 0.27 & 0.23 & 0.25 & 0.25 & 0.23 & 0.24 & 0.19 \\
\hline & & 625 & 0.26 & 0.26 & 0.26 & 0.25 & 0.24 & 0.24 & 0.26 & 0.22 & 0.23 & 0.23 \\
\hline
\end{tabular}


The temperature during the test was approximately $0{ }^{\circ} \mathrm{C}$ with a range of $\pm 0.3^{\circ} \mathrm{C}$ (Fig. 2). There was no strong wind or active precipitation, except for some very light snowfall at noon.

\section{Results}

\subsection{Surface wear}

Figures 3, 4 and 5 show examples of the wear of the road surfaces. The icy surfaces did not wear markedly during the test (Fig. 3), but those covered with compact snow wore down faster than expected and somewhat inconsistently as well. Figure 4 shows the braking section driven by $100 \%$ of vehicles with studded tyres midway through the test. At the end of the test the compact snow had worn away entirely in several places (Fig. 5).

\subsection{Friction coefficient by proportion of vehicles with studded tyres}

Figures 6 and 7 show the overall friction coefficient measured in section A for vehicles with studded and unstudded tyres, respectively. The results show that the effect on friction of reducing the number of vehicles with studded tyres was relatively small when the proportion of vehicles with studded tyres was $50 \%$ or higher. When the corresponding proportion was $25 \%$ or $0 \%$ the friction was substantially lower, especially during later phases of the test. The friction difference between the outermost test lanes was evident quite early, after 200-300 runs.

The disaggregated results for the test lanes in section A are given in Table 2. As expected, the detailed results include more variance than the summary results in Fig. 6. However, the same pattern as in Figs. 6 and 7 is evident by observing the highlighted cells indicating drops in friction of more than $10 \%$ and $20 \%$. In addition, the highest friction at the end of test is always found for the lane involving 50-100\% of vehicles with studded tyres, and the lowest for the lane with $0-25 \%$ of vehicles with studded tyres.

There are some differences in the results by subsection. Specifically, at the end of the test, the largest (24-31\%) mean friction reductions compared to the lane with $100 \%$ of vehicles with studded tyres were found for sections with constant speed and braking, whereas the friction dropped less (13$19 \%$ ) in the acceleration section. However, the largest reductions in each section were for the lane with $100 \%$ of vehicles with unstudded tyres regardless of tyre type of the measurement vehicle.

Because the section with compact snow wore inconsistently, the results include more variance than those for the icy surface, but we consider them to correspond relatively well with the latter. Specifically, compared to the lane with $100 \%$ of vehicles with studded tyres at the end of the test, the largest

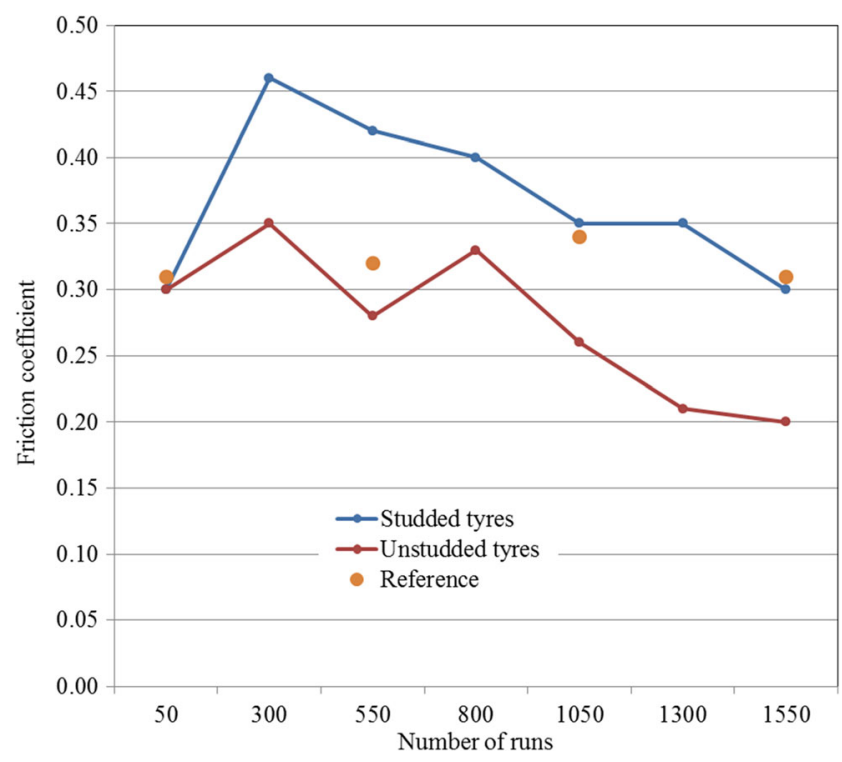

Fig. 8 Friction coefficient in section B measured by the vehicle with studded tyres, by number of runs

mean friction reduction was $22-23 \%$ on snow-covered surfaces and $20-31 \%$ on ice-covered surfaces.

Figures 8 and 9 show the overall friction results in section $\mathrm{B}$ measured for vehicles with studded and unstudded tyres, respectively. The friction differed substantially between the lanes having $100 \%$ or $0 \%$ of vehicles with studded tyres and driving at constant speed. The difference emerged after 300 runs and remained fairly constant to the end of the test (1550 runs).

The friction in the test lanes in section B increased at the start of the test but then fell continuously until the end of the test. This is consistent with the results for the test lanes in section A. However, the friction in the reference lane in

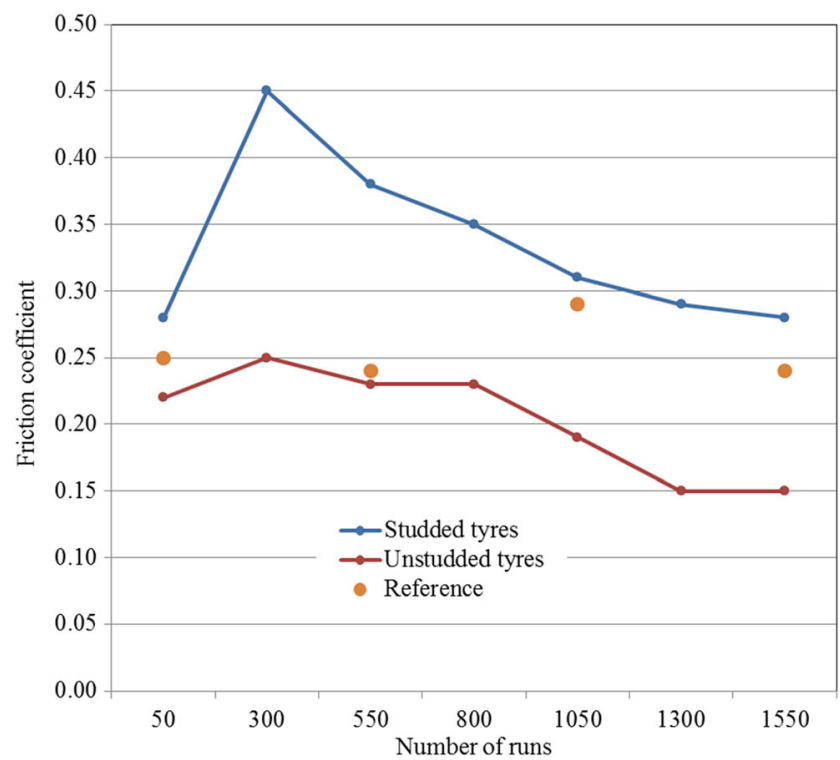

Fig. 9 Friction coefficient in section B measured by the vehicle with unstudded tyres, by number of runs 
Table 3 Mean depth of ruts $(\mathrm{cm})$ in section A by road surface, subsection and lane. The results are given for the beginning, middle and end of the test. The missing values (-) are for measurements outside the range of the profile gauge

\begin{tabular}{|c|c|c|c|c|c|c|c|}
\hline \multirow[t]{2}{*}{ Subsection } & \multirow[t]{2}{*}{ Phase of test } & \multicolumn{5}{|c|}{ Proportion of vehicles with studded tyres } & \multirow[t]{2}{*}{ Reference lane } \\
\hline & & $100 \%$ & $75 \%$ & $50 \%$ & $25 \%$ & $0 \%$ & \\
\hline \multicolumn{8}{|l|}{ Icy road surface } \\
\hline \multirow[t]{3}{*}{ Constant speed } & Beginning & 0.1 & 0.1 & 0.2 & 0.2 & 0.3 & 0.4 \\
\hline & Middle & 0.3 & 0.4 & 0.3 & 0.3 & 0.2 & 0.2 \\
\hline & End & 0.4 & 1.0 & 0.3 & 0.4 & 0.1 & 0.2 \\
\hline \multirow[t]{3}{*}{ Braking } & Beginning & 0.1 & 0.3 & 0.2 & 0.1 & 0.0 & 0.0 \\
\hline & Middle & 1.5 & 0.3 & 0.3 & 0.1 & 0.1 & 0.2 \\
\hline & End & 1.3 & 0.8 & 0.5 & 0.2 & 0.4 & 0.1 \\
\hline \multirow[t]{3}{*}{ Acceleration } & Beginning & 0.1 & 0.4 & 0.1 & 0.1 & 0.1 & 0.2 \\
\hline & Middle & 0.8 & 0.2 & 0.1 & 0.1 & 0.2 & -0.1 \\
\hline & End & - & 0.6 & 0.5 & 0.3 & 0.3 & 0.3 \\
\hline \multicolumn{8}{|c|}{ Snowy road surface } \\
\hline \multirow[t]{3}{*}{ Constant speed } & Beginning & 0.2 & 0.0 & 0.2 & 0.2 & 0.3 & 0.2 \\
\hline & Middle & 1.2 & 0.9 & 0.7 & 0.8 & - & 0.1 \\
\hline & End & - & - & - & - & - & 0.2 \\
\hline \multirow[t]{3}{*}{ Braking } & Beginning & 0.1 & 0.2 & 0.1 & -0.3 & 0.2 & 0.0 \\
\hline & Middle & - & - & - & 1.9 & - & 0.2 \\
\hline & End & - & - & - & & - & 0.1 \\
\hline \multirow[t]{3}{*}{ Acceleration } & Beginning & 0.2 & 0.2 & 0.4 & 0.1 & 0.2 & 0.4 \\
\hline & Middle & 1.9 & - & & 0.7 & - & 0.2 \\
\hline & End & - & - & - & - & - & 0.1 \\
\hline
\end{tabular}

section $\mathrm{B}$ was quite constant throughout the test, whereas that in the reference lane in section A decreased somewhat.

\subsection{Effects of Tyre type on depth of ruts}

Table 3 shows the effects of tyre type on rut depth in section A. There was substantial variance among individual findings, and several values are missing because the road surface wore quickly, most often in the section with compact snow. However, the following overall findings are evident: On icy surfaces, the more vehicles there were with studded tyres, the deeper the mean depth of ruts was at the end of the test. Conversely, there was virtually no increase in depth in the reference lane or in the lane involving no vehicles with studded tyres.

\section{Discussion}

The aim of this study was to compare to what degree various proportions of studded and unstudded winter tyres affect the roughness and polishing of road surfaces covered with ice and compact snow. The test was conducted on a track including two straight sections. The main section had five test lanes, each with a different proportion of cars with studded tyres: $100 \%, 75 \%, 50 \%, 25 \%$ and $0 \%$ of the respective lane traffic.
Each test lane included sections of ice and compact snow with subsections for constant speed, braking and acceleration. Another section had two lanes for driving at constant speed: one for cars with studded tyres and one for cars with unstudded tyres. The lane in this section was covered with compact snow. The total number of runs per test lane was 642 in the main section and 1605 in the second section.

The main results show that the effect on friction of reducing the number of vehicles with studded tyres was relatively low when the proportion of vehicles with studded tyres was $50 \%$ or more. When the corresponding proportion was $25 \%$ or $0 \%$, the friction was substantially lower, especially at the end of the test. The friction difference between the outermost test lanes was evident already after 200-300 runs.

Compared to the results of Tuononen and Sainio [14], our results suggest a somewhat higher proportion of studded tyres for adequate friction on wintry road surfaces, although the range suggested by Tuononen and Sainio includes $50 \%$ of vehicles with studded tyres. It is assumed that differences in test conditions (e.g. temperature) and a higher usage of test lanes in our test might be responsible for this discrepancy. Vaa and Giaever [15] did not provide any specific conclusion in terms of needed proportion of studded tyres.

The results by subsection show that at the end of test, the greatest reductions (24-31\%) in mean friction compared to the 
lane with $100 \%$ of vehicles with studded tyres were found for sections of constant speed and braking, whereas the friction dropped less (13-19\%) in the acceleration section. All of the greatest reductions were for the lane with $100 \%$ of vehicles with unstudded tyres. This trend was evident for both tyre types of the measurement vehicle.

Because the section with compact snow wore inconsistently, the results include more variance than those for the icy surface, but we consider that the results for the compact snow surface correspond relatively well to those obtained for icy surfaces.

The effects of tyre type on rut depth show that the depth increased much faster on compact snow than on ice during the test. In fact, the snowy surface wore so quickly and inconsistently that we were unable to accurately measure the increase in ruts. However, on icy surfaces, the more vehicles there were with studded tyres, the deeper the mean depth of ruts was at the end of the test.

Our main conclusion is that in the reported test conditions, traffic with $50 \%$ of cars having studded tyres results in adequate friction of icy road surfaces. With lower proportions of studded tyres, the friction is substantially lower. If authorities aim to discourage the use of studded tyres by introducing a tax for their use, as in major cities in Norway [6] for example, the proportion of studded tyres could be influenced by the size of the tax.

However, any single study is unlikely to provide a full picture of the needed proportion of studded tyres for sufficient friction, given that road conditions keep changing and there are other factors affecting friction as well. For example, winter maintenance aims to keep friction at an acceptable level and there are heavy vehicles in real traffic that may wear snow or ice more quickly than cars but may also polish icy road surfaces. Consequently, the main contribution of these results is to provide one piece of evidence for decision making, if the societal goal is to reduce the adverse effects of studded tyres without hampering road safety.

Acknowledgements Appreciation is extended to the members of the research programme Traffic Safety 2025 for their support of this research. The current members are the Finnish Transport Agency, Finnish Transport Safety Agency, Nokian Tyres and VTT Technical Research Centre of Finland. The authors also wish to thank Mika Loponen from the Finnish Transport Safety Agency and Tommi Ajoviita, Teemu Soini and Mikko Liukkula from Nokian Tyres for their valuable consultation and advice. Teemu Pitkänen and Tomi Nieminen from Nokian Tyres helped with the data collection. Nokian Tyres provided the test track and assisted with recruiting the test drivers.
Open Access This article is distributed under the terms of the Creative Commons Attribution 4.0 International License (http:// creativecommons.org/licenses/by/4.0/), which permits unrestricted use, distribution, and reproduction in any medium, provided you give appropriate credit to the original author(s) and the source, provide a link to the Creative Commons license, and indicate if changes were made.

\section{References}

1. Anila M, Alppivuori K (1994) Lumipolanteen kiillottuminen [Polishing of road surface covered by compact snow]. Internal Reports of Road Administration 39/1994. Road Administration, Helsinki

2. Anila M, Kallberg VP (1994) Nastarenkaiden vaikutus polanteen kulumisnopeuteen ja tienpinnan kitkaominaisuuksiin [Effects of studded tyres on wear and friction on road surface covered by compact snow]. Internal Reports of the Road Administration 26/ 1994. Road Administration, Helsinki

3. ASTM International (2008) Standard test method for single wheel driving traction in a straight line on snow- and ice-covered surfaces http://www.astm.org. Accessed 9 Feb 2016

4. Elvik R (1999) The effects on accidents of studded tires and laws banning their use: a meta-analysis of evaluation studies. Accid Anal Prev 31:125-134

5. Elvik R (2015) Can electronic stability control replace studded tyres? Accid Anal Prev 85:170-176

6. Elvik R, Fridstrøm L, Kaminska J, Meyer SF (2013) Effects on accidents of changes in the use of studded tyres in major cities in Norway: a long-term investigation. Accid Anal Prev 54:15-25

7. Hjort M (2013) Measuring tyre performance in ESC intervention situations. In: Proceedings of the International Conference Science Meets Tires: Perspectives for Tire Technology, Aachen, September 11-12. The Institute of Plastics Processing (IKV) and the Institute for Automotive Engineering (ika) of RTWH Aachen University, Aachen

8. Hjort M, Jansson J (2010) Handling of buses in slippery roads during the influence of side wind - a study of the effects of different tyres. Accid Anal Prev 42:972-977

9. Kupiainen KJ, Pirjola L (2011) Vehicle non-exhaust emissions from the Tyre-road interface - effect of stud properties, traction sanding and resuspension. Atmos Environ 45:4141-4146

10. Malmivuo M, Luoma J, Porthin M (2016) Studded and unstudded winter tyres in fatal road accidents in Finland. Traffic Inj Prev. doi:10.1080/15389588.2016.1243239

11. Roine M (1999) Accident risks of car drivers in wintertime traffic. VTT Publications 401. VTT Technical Research Centre of Finland, Espoo

12. Strandroth J, Rizzi M, Olai M, Lie A, Tingvall C (2012) The effects of studded tires on fatal crashes with passenger cars and the benefits of electronic stability control (ESC) in Swedish winter driving. Accid Anal Prev 45:50-60

13. Svendenius J, Gäfvert M, Bruzelius F, Hultén J (2009) Experimental validation of the brush tire model. Tire Sci Technol 37:122-137

14. Tuononen A, Sainio P (2014) Optimal proportion of studded tyres in traffic flow to prevent polishing of an icy road. Accid Anal Prev 65:53-62

15. Vaa T, Giaever T (2004) Vinterfriksjonsprosjektet - Studie på konsekvenser av endret piggdekkbruk, Norsk Trafikksenter 2003. Intern rapport nr. 2369. Statens vegvesen, Oslo 